\title{
Devitrification Phenomenon and Physical Properties of Calcium Phosphate Glasses with Various $\mathrm{CaO} / \mathrm{P}_{2} \mathrm{O}_{5}$ Mole Ratios
}

\author{
C.K. Hsu ${ }^{1,3}$ J.S. Lee ${ }^{1,2}$, and C.W. Huang ${ }^{1}$ \\ 1.Department of Chemistry, Chung Yuan Christian University Chungli, 32023, Taiwan, \\ R.O.C. \\ 2.P.O.Box. No.90008-15-9, Chung Shan Institute of Science and Technology, Lungtan, \\ Taiwan, R.O.C. \\ 3.Department of Materials \& Mineral Resources Engineering, National Taipei Institute of \\ Technology, Taipei, Taiwan, R.O.C.
}

\begin{abstract}
The devitrification mechanisms of various $\mathrm{CaO} / \mathrm{P}_{2} \mathrm{O}_{5}$ mole ratios calcium phosphate glasses were investigated by non-isothermal DTA technique and by observing the devitrification phenomenon of tested samples after heat treatment procedures. It was found that the devitrification mechanism changed from bulk nucleation to surface nucleation, owing to decreasing the $\mathrm{CaO} / \mathrm{P}_{2} \mathrm{O}_{5}$ mole ratio of calcium phosphate glasses.

The major crystalline phase of the resultant products was $\beta-\mathrm{Ca}\left(\mathrm{PO}_{3}\right)_{2}$, the crystalline characteristic was examined by XRD and EDS. The rod-like type $\beta-\mathrm{Ca}\left(\mathrm{PO}_{3}\right)_{2}(5 \mu \mathrm{m}$ in diameter and $60 \mu m$ in length) crystal was observed from the of SEM micrograph.
\end{abstract}

\section{INTRODUCTION}

The devitrification of the glasses in the system $\mathrm{CaO} / \mathrm{P}_{2} \mathrm{O}_{5}$ with high $\mathrm{Ca} / \mathrm{P}$ mole ratio has been investigated by many researchers ${ }^{[1,2]}$. In this study, the devitrification mechanism of calcium phosphate glasses with low $\mathrm{CaO} / \mathrm{P}_{2} \mathrm{O}_{5}$ mole ratios was studied by non-isothermal differential thermal analysis technique. The devitrification phenomenon of calcium phosphate glasses with various $\mathrm{CaO} / \mathrm{P}_{2} \mathrm{O}_{5}$ mole ratios were examined by the observation of the resultant products under different heat treatment conditions. In this work, $\beta-\mathrm{Ca}\left(\mathrm{PO}_{3}\right)_{2}$ crystal was found by traditional melting method. How to enhance the moisture resistance of lower $\mathrm{CaO} / \mathrm{P}_{2} \mathrm{O}_{5}$ mole ratio calcium phosphate, and the separating technique of $\beta-\mathrm{Ca}\left(\mathrm{PO}_{3}\right)_{2}$ crystal from calcium phosphate glasses are the major goal in the future.

\section{EXPERIMENTALS PROCEDURE}


The compositions of different raw materials were listed in Table 1. Batch mixtures with $\mathrm{CaO} / \mathrm{P}_{2} \mathrm{O}_{5}=0.72,0.85$, $1.0,1.1$ in mole ratios were prepared by mixing $\mathrm{Ca}\left(\mathrm{H}_{2} \mathrm{PO}_{4}\right)_{2} \cdot \mathrm{H}_{2} \mathrm{O}, \mathrm{CaCO}_{3}$ and $\mathrm{H}_{3} \mathrm{PO}_{4}$. The mixtures were mixed with ethanol in a ball miller for 30 minutes. After being dried, the mixtures were melted in a platinum crucible at $850{ }^{\circ} \mathrm{C}$ for 30 minutes, then $1250{ }^{\circ} \mathrm{C}$ for 2 hours. The melts were poured onto a preheated graphite plate $\left(280^{\circ} \mathrm{C}\right)$ and cooled to room temperature. The sample powder was prepared by crushing the glass in an agate mortar, then sieved in order to obtain fine $(-325$ mesh $)$ and coarse $(-30+50$ mesh $)$ particle. The DTA curves for each $30 \mathrm{mg}$ sample of glass powder were recorded in air atmosphere at different heating rates $\left(2^{\circ} \mathrm{C} \min ^{-1}\right.$ to 20

${ }^{\circ} \mathrm{C} \min ^{-1}$ ). A Rigaku-Denki thermoanalyzer (model 8121) was used, and powdered $\alpha-\mathrm{Al}_{2} \mathrm{O}_{3}$ was used as a reference material.

The glass $\left(\mathrm{CaO} / \mathrm{P}_{2} \mathrm{O}_{5}=0.72\right)$ obtained from graphite plate was reheated at nucleation temperature $\left(575^{\circ} \mathrm{C}\right)$ for 2 hours then at crystallization temperature $\left(664^{\circ} \mathrm{C}\right)$ for 8 hours. The crystalline phases in the resultant products were identified by a Rigaku-Denki X-ray diffraction analyzer(XRD). The crystalline morphologies were observed by a JEOL JSM-6300 Scanning Electron Microscopy(SEM). The physical properties such as Vicker's surface hardness, weight loss percentage after dipping in Ringer's solution for 14 days were examined.

\section{RESULTS AND DISCUSSION}

In some cases, non-isothermal differential thermal analysis(DTA) technique is not enough to explain the kinetic results from strictly physical and/or physicochemical point of view. ${ }^{(3,4)}$ To compensate DTA, the modified Kissinger equation $(5,6)$ has been widely used for the kinetic study of the non-isothermal crystallization glasses.

$\ln h^{\mathrm{n}} / T p^{2}=-m E_{\mathrm{G}} / R T p+$ const.

where $\mathrm{h}$ is the heating rate $\left({ }^{\circ} \mathrm{C} \min ^{-1}\right)$, and Tp is the exothermic peak temperature of DTA thermograph. $E_{G}$ is the activation energy of crystal growth, $\mathrm{R}$ is the gas constant, the parameter $\mathrm{n}$ and $\mathrm{m}$ are dependent on the morphology of the devitrification, while in the Kissinger plots $n=m=1$. Table 2 lists the apparent activation energies for these samples. The activation energy of devitrification decreased with decreasing $\mathrm{CaO} / \mathrm{P}_{2} \mathrm{O}_{5}$ mole ratios of the calcium phosphate glasses, when the glass particle size was less than $44 \mu_{\mathrm{m}}$, this is not true for the glasses at particle size ranging from 297 to $590 \mu_{\mathrm{m}}$. According the isothermal crystallization data of $\mathrm{Ca}\left(\mathrm{PO}_{3}\right)_{2}$ glass powders 44 to $74 \mu_{\mathrm{m}}$ in size, for $\mathrm{Y}$. Abe etc. ${ }^{(7)}$ the $\mathrm{E}_{\mathrm{G}}(=500 \mathrm{KJ} / \mathrm{mole})$ was estimated by the relation between $\mathrm{t}_{0.5}$ and temperature. When the values $\mathrm{n}=3$ and $\mathrm{m}=2$ for coarse A glasses, the activation energy $E_{a p p}$ has a value closet to the $\mathrm{E}_{\mathrm{G}}$ described above. This indicates that the devitrification mechanism of the large particle size fraction is bulk nucleation an three dimensional growth.

In general, the exothermic peak of DTA curves for a coarse sample give more sharply than a fine sample at same heating rate. And the DTA exothermic peak is observed at a lower temperature for the smaller particle sizes, when the crystallization is regulated by the surface crystallization mechanism. However, the temperature region for the invariant irrespective of particle size, as expected from the constant $\mathrm{Tp}$ for the volume crystallization ${ }^{\left({ }^{(8)}\right.}$

Fig.1 shows the DTA crystallization peaks, two types of particle size for calcium phosphate glasses with various $\mathrm{CaO} / \mathrm{P}_{2} \mathrm{O}_{5}$ mole ratios, at a heating rate of $10{ }^{\circ} \mathrm{C} \mathrm{min}^{-1}$. As shown in Figure $1, T_{p}$ increases with increasing the particle size. For the A glass, the Tp of glass powder which after nucleation procedure was very closed to the $\mathrm{Tp}$ of coarse glass, this also say that bulk nucleation devitrification mechanism was occurred in A glass.

The X-ray diffraction (XRD)analysis of the resultant product of glass $\mathrm{D}$ under different heat treatment conditions are shown in Fig.2. It is found that the intensity of characteristic peaks for $\beta-\mathrm{Ca}\left(\mathrm{PO}_{3}\right)_{2}$ crystalline were very clear. $\mathrm{XRD}$ analysis showed that a large amount of $\beta-\mathrm{Ca}\left(\mathrm{PO} \mathrm{O}_{3}\right)_{2}$ crystal exist in the crystallized product of lower $\mathrm{CaO} / \mathrm{P}_{2} \mathrm{O}_{5}$ mole ratio calcium phosphate glasses. The surface microstructure of the resultant product of glass $\mathrm{D}$ is shown in Fig.3. The rod-like morphology is $\beta-\mathrm{Ca}\left(\mathrm{PO}_{3}\right)_{2}$ crystalline, which with $5 \mu \mathrm{m}$ in diameter and $60 \mu \mathrm{m}$ in length. And the aspect ratio was 12 , the fiber-like $\beta-\mathrm{Ca}\left(\mathrm{PO}_{3}\right)_{2}$ crystals can be extract by using a leaching solution. The composition of $\left.\beta-\mathrm{Ca}(\mathrm{PO})_{2}\right)_{2}$ crystalline analysis by EDX is shown in Fig.4. The weight percentage of oxides is approximately equal to the composition of 
$\beta-\mathrm{Ca}\left(\mathrm{PO}_{3}\right)_{2}$ crystalline, this is an another evidence to indicate that the crystal of glass $\mathrm{D}$ is $\beta-\mathrm{Ca}\left(\mathrm{PO}_{3}\right)_{2}$ crystalline.

Glass-ceramic composed of crystalline $\beta-\mathrm{Ca}\left(\mathrm{PO}_{3}\right)_{2}$ fiber with $\mathrm{Ca} .1 \mu \mathrm{m}$ diameter exhibits extremely high bending strength of 400-600 Mpa and low Young's modulus of 70-120 Gpa, this result implies that $\beta-\mathrm{Ca}\left(\mathrm{PO}_{3}\right)_{2}$ fiber are high-strength and flexibility. ${ }^{(9)}$ Vicker's surface hardness gave some relationship with strength, i.e., the higher values of hardness, the higher strength of material. The Vicker's surface hardness of the resultant products under various heat treatment conditions were shown in Fig. 5. The resultant product of glass $\mathrm{C}$ appeared the highest Vicker's surface hardness, $670 \mathrm{~kg} / \mathrm{mm}^{2}$. And the Vicker's surface hardness increased with increasing the time of crystal growth. The biodegradation weight loss percentage of calcium phosphate glasses with different $\mathrm{CaO} / \mathrm{P}_{2} \mathrm{O}_{5}$ mole ratios were investigated by dipped the resultant products in Ringer's solution for 14 days. The weight loss percentage of glass $\mathrm{D}$ shows a highest weight loss percentage at a maximum value of $0.26 \%$. The average weight loss percentage of glass $\mathrm{A}$ is lower than $0.1 \%$. In order to evaluate the biocompatibility of calcium phosphate glass-ceramics with lower $\mathrm{CaO} / \mathrm{P}_{2} \mathrm{O}_{5}$ mole ratios, more detail biodegradation experiments should be done.

\section{SUMMARY}

The following conclusions can be drawn from this study.

(1) The activation energy of devitrification for the calcium phosphate glasses with various $\mathrm{CaO} / \mathrm{P}_{2} \mathrm{O}_{5}$ mole ratios decreased with decreasing $\mathrm{CaO} / \mathrm{P}_{2} \mathrm{O}_{5}$ mole ratios at particle size less than $44 \mathrm{\mu m}$.

(2) .By decreasing the $\mathrm{CaO} / \mathrm{P}_{2} \mathrm{O}_{5}$ mole ratios of the calcium phosphate glasses, the devitrification mechanism changed from bulk nucleation to surface nucleation

(3) The major crystalline phase of glass $\mathrm{D}$ developed after heat treatment was $\beta-\mathrm{Ca}(\mathrm{PO})_{2}$. The shape of $\beta-\mathrm{Ca}\left(\mathrm{PO}_{3}\right)_{2}$ crystalline is the rod-like type with $5 \mu \mathrm{m}$ in diameter and $60 \mu \mathrm{m}$ in length.

(4) The maximum Vicker's surface hardness of resultant product was at $670 \mathrm{~kg} / \mathrm{mm}^{2}$.

\section{REFERENCES}

1. A.Watanade, M. Mitsudou, S. Kihara and Y. Abe. J. Am. Ceram. Soc., 72, [8] (1989) 1499-1500.

2. A. Krajewski and A. Ravaglioli. Biomaterial vol.2 (1981) 105.

3. J. Sestak, Thermochim. Acta, 98(1986) 339.

4. J. Sestak, ibid,203(1992) 361.

5. .K. Matushita and S. Sakka, J. Non-Cryst. Solids, $\underline{38,39}$ (1980)741.

6, K. Matushita, T. Komatu and R.yokota, J. Mater. Sci.,19 (1984)291.

7. Y. Abe, T. Arahori and A. Naruse, J. Am ceram. Soc., vol 59, No 11-12(1976)487.

8. A. Marotta and A.Buri, Thermochim. Acta,25(1987) 155.

9. T. Kasuga,A.Ichino and Y. Abe, J.Ceram.Soc.,Japan, 100[8] (1992)1088

Table 1 Composition of calcium phosphate glasses.

\begin{tabular}{|c|c|c|c|}
\hline \multirow{2}{*}{ Glass } & \multicolumn{3}{|c|}{ Composition } \\
\cline { 2 - 4 } & $\mathrm{Ca}\left(\mathrm{H}_{2} \mathrm{PO}_{4}\right) \cdot \mathrm{H}_{2} \mathrm{O}$ & $\mathrm{CaCO}_{3}$ & $\mathrm{H}_{3} \mathrm{PO}_{4}$ \\
\hline A & 90.9 & 9.1 & 0 \\
\hline B & 100 & 0 & 0 \\
\hline C & 73.9 & 0 & 26.1 \\
\hline D & 53.8 & 0 & 40.2 \\
\hline
\end{tabular}


Table 2 Apparent activation energies $\mathbf{E}_{\text {app }}$ calculated using the Kissinger method for the nonisothermal crystallization of $\mathrm{CaO} / \mathrm{P}_{2} \mathrm{O}_{5}$ glasses.

\begin{tabular}{|c|c|c|c|c|c|c|c|c|c|c|c|c|}
\hline \multirow{2}{*}{$\mathrm{mm}$} & \multicolumn{4}{|c|}{ Range of $T_{p}\left({ }^{\circ} C\right)$} & \multicolumn{4}{|c|}{ Eapp(KJmole $\left.{ }^{-1}\right)$} & \multicolumn{4}{|c|}{$-\gamma^{a}$} \\
\hline & $\mathbf{A}$ & B & C & D & $\mathbf{A}$ & B & C & D & $\mathbf{A}$ & B & C & D \\
\hline$<0.044$ & $591 \sim 624$ & $620-664$ & $666-656$ & $625-684$ & 442 & 347 & 299 & 266 & 0.9993 & 0.9983 & 0.9994 & 0.9961 \\
\hline $0.297 \sim 0.59$ & $640-690$ & $661 \sim 707$ & $654-699$ & $685 \sim 742$ & 325 & 356 & 348 & 301 & 0.9996 & 0.9985 & 0.9788 & 0.9875 \\
\hline
\end{tabular}

A, B, C, D are glasses, the composition were listed in Table 1.

$-\gamma^{a}$ :Correlation coefficient for the linear regression analysis of the Kissinger plot.

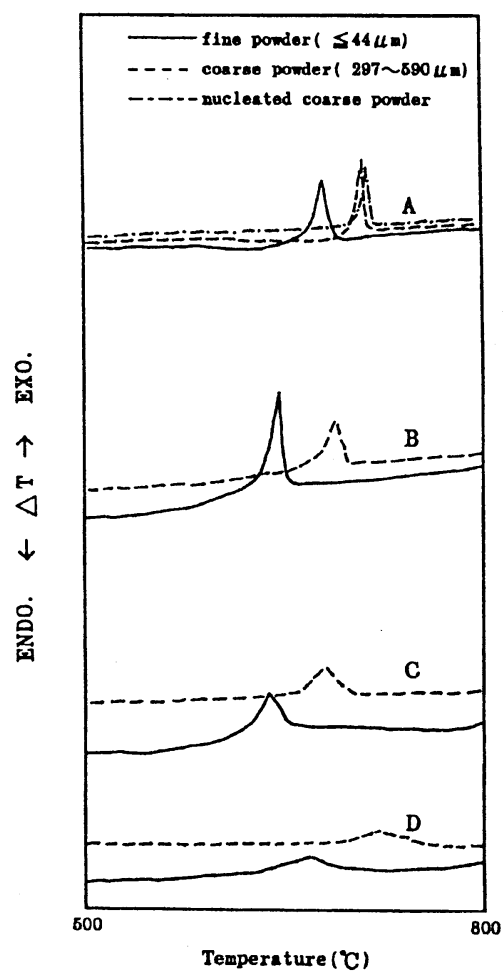

FIGURE 1 . The thermograms of calcium phosphate glasses with various $\mathrm{CaO} / \mathrm{P}_{2} \mathrm{O}_{5}$ mole ratio with different particle size fractions, heating rate $=10^{\circ} \mathrm{C} / \mathrm{min}$.

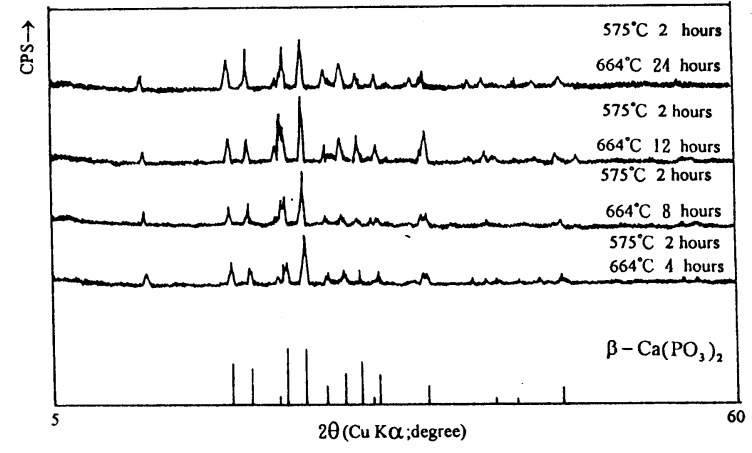

FIGURE 2. The X-ray diffraction analysis of the result product of glass $D$ under different heat treatment conditions.

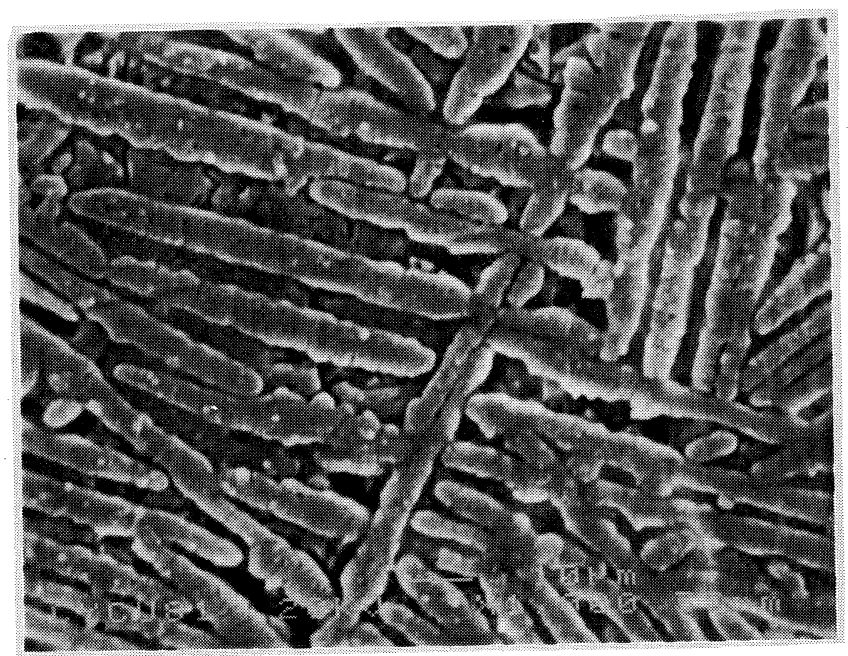

FIGURE 3 . The surface micrograph of $\beta-\mathrm{Ca}\left(\mathrm{PO}_{3}\right)_{2}$ crystalline. 

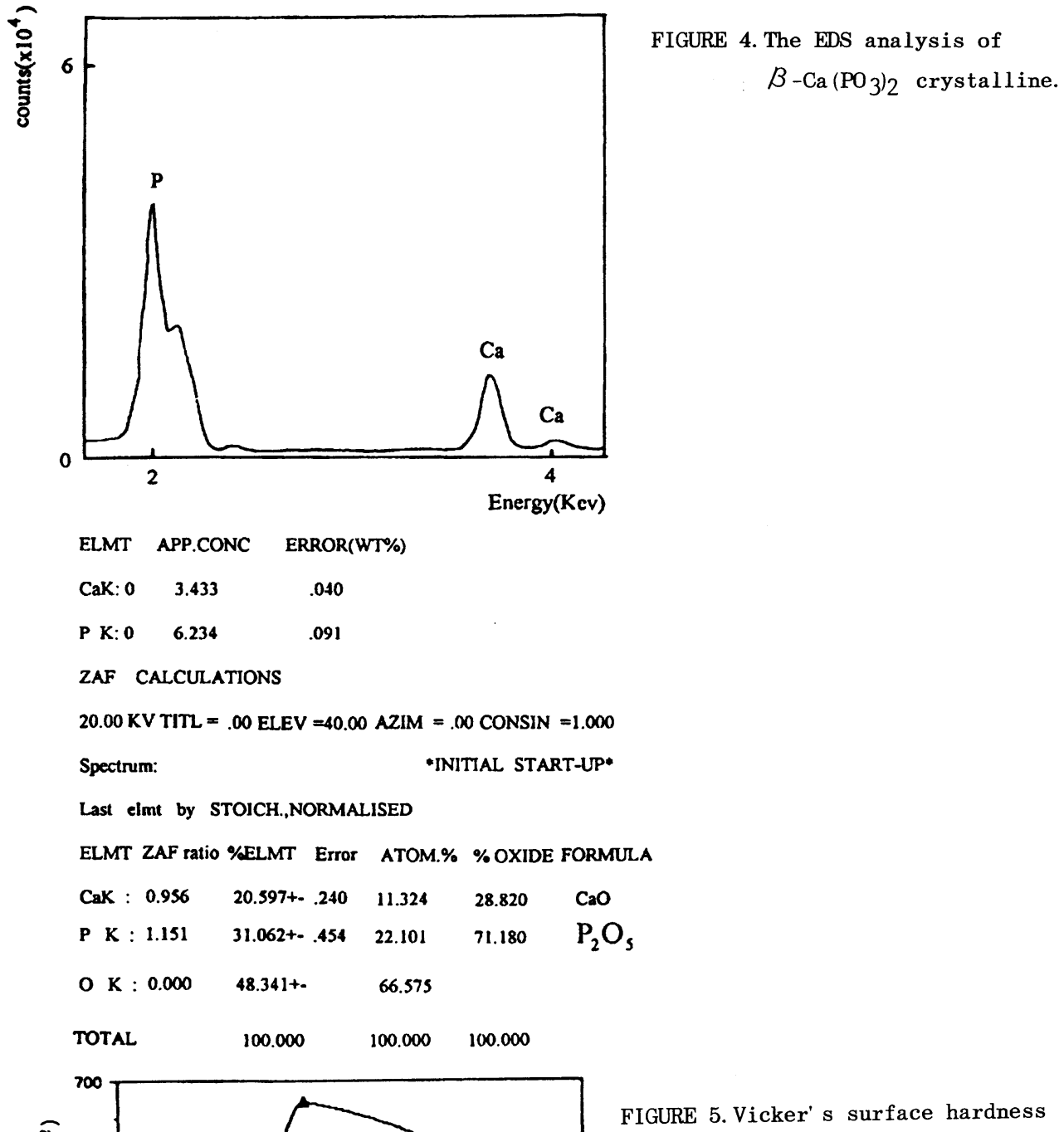
for resulant products. 